УДК 94(47).031

DOI: $10.22378 / 2313-6197.2017-5-2.325-343$

\title{
THE IMPACT OF THE BLACK DEATH ON THE GOLDEN HORDE: POLITICS, ECONOMY, SOCIETY, CIVILIZATION
}

\author{
Uli Schamiloglu \\ University of Wisconsin-Madison \\ Madison, USA \\ uschamil@wisc.edu
}

Research objectives and materials: This essay offers an overview of the political, economic, social, and cultural consequences of the Black Death (the epidemic of bubonic plague cause by the bacteria Yersinia pestis) in the territories of the Golden Horde in the $14^{\text {th }}-15^{\text {th }}$ centuries. It considers the framework which has been developed for medieval Europe and the Middle East. It considers whether there was a medieval growth in population in the Golden Horde prior to the arrival of the Black Death in the mid- $14^{\text {th }}$ century. It considers the level of depopulation and how it led to political instability. It notes how bubonic plague was used as a weapon by the Mongol armies. It considers economic consequences such as the decline in certain professions and crafts, the threat to the food supply, and the rising cost of labor which led to inflation. It also considers the social crisis brought about by the sudden death of substantial portions of the population.

Results and novelty of the research: The rise in urbanization in the $13^{\text {th }}$ to mid-14 century was followed by a collapse in the population and decline in urban centers beginning in the second half of the $14^{\text {th }}$ century. The Black Death also led to population pressure as most sedentary centers declined, while at the same time certain sedentary areas escaped the plague, as could many nomadic populations who were less susceptible to disease. It also examines the decline in literary languages and the growth in religiosity. Finally, it considers the recovery in the population beginning in the mid- $15^{\text {th }}$ century.

Keywords: Black Death, depopulation, political instability, economic crisis, social crisis, deurbanization, literary languages, religiosity

For citation: Schamiloglu U. The Impact of the Black Death on the Golden Horde: Politics, Economy, Society, Civilization. Zolotoordynskoe obozrenie $=$ Golden Horde Review. 2017. Vol. 5, no. 2, pp. 325-343. DOI: 10.22378/2313-6197.2017-5-2.325-343

This essay considers the question of the political, social, economic, and cultural transformations in Central Eurasia as a result of the Black Death during the time of the Golden Horde $\left(13^{\text {th }}-14^{\text {th }}\right.$ centuries $)$. The Black Death was the second of three major waves of deadly pandemic caused by the bacteria Yersinia pestis. The first wave was the Plague in the Time of Justinian from the mid- $6^{\text {th }}$ to the mid- $8^{\text {th }}$ centuries [see my: 37]. The third wave was modern plague beginning in the late $19^{\text {th }}$ century [for studies of modern plague see: 23]. The geographic point of origin of the plague is now believed to have been the Qinghai-Tibet Plateau. The plague, transmitted by rodents and fleas feeding on both rodents and humans, reached Lake Isıq-köl in 1338-1339. Arab writers in the Middle East inform us that the disease had begun in Central Asia and had been raging there for 15 years. The Russian sources indicate that it struck the cities of the Golden Horde, including Saray and Astrakhan. The disease then appeared in the Crimea in 1346 [for the sources see my: $43 ; 52$, p. 686-690; and 41]. From there the disease spread to Constantinople, 
and from there to Alexandria in Egypt and Sicily in Italy [on the Black Death in Constantinople see my: 42]. The disease spread widely across the Middle East, Europe, and beyond. It ravaged these world regions in multiple waves for many years, with waves of the Black Death continuing in the territories of the Golden Horde apparently until the $15^{\text {th }}$ century. In this essay I will take as my starting point some of the topics considered by David Herlihy and other scholars for medieval Europe and the Middle East [see 18; 6; 13; and 9] ${ }^{1}$ and explore additional topics based upon my own research on the Golden Horde in order to offer some thoughts in an attempt to provide a general overview of the political, economic, social, and cultural legacy of the Black Death in the territories of the Golden Horde and its successor states.

\section{Earlier population growth vs. Black Death-era depopulation?}

It is believed that in Western Europe population was on the rise prior to the arrival of the Black Death in the mid-14 ${ }^{\text {th }}$ century. According to Herlihy, by 1300 many communities in medieval Europe had attained a large size: the population of the region of Tuscany, for example, reached about two million inhabitants. Scholars also believe that high prices for cereals and occurrences of famine in this period also offer indirect evidence of overpopulation. In Languedoc there were 27 years of adequate food supply but 20 years of scarcity during the period 1302 1348. In Northern Europe the period 1314-1317 was a period of famine known traditionally as the "Great Hunger". There was also famine in Florence in 13461347 on the eve of the arrival of the Black Death: only $20 \%$ of the population had access to bread, with the rest foraging in the countryside. Indeed, as Herlihy points out, some scholars have considered what was to transpire upon the arrival of the Black Death as a "Malthusian crisis" of overpopulation [see 18, p. 31-33. On the crisis of the early $14^{\text {th }}$ century see also the essays in 10].

Can we describe a parallel situation for the territory of the Golden Horde, namely that it, too, was experiencing overpopulation in this period before the arrival of the Black Death? It is difficult to make such a blanket statement. It does appear that there was some significant nomadic population which arrived in the western part of Central Eurasia from areas further to the east with the Mongol conquests in the first half of the $13^{\text {th }}$ century. Given the rich pasturage along the lower Volga River and other river systems, perhaps this enabled a better-nourished population to grow in number. We also have a sense of the growth of urban centers, probably representing an expanding population as well.

With the arrival of the Black Death in the territories of the Golden Horde in the $1340 \mathrm{~s}$ - the precise chronology and paths of which may never be fully elucidated - we must assume that there were very high levels of mortality in many regions. If we consider the effects upon Western Europe, it will help us to imagine what its impact might have been on Central Eurasia. As noted above, on the eve of the Black Death the population of Tuscany had reached about two million inhabitants. After the Black Death and everything else transpiring after its arrival, Tuscany would not reach the level of population it had once had at the beginning of the $14^{\text {th }}$ century until after 1850 . The demographic impact of the Black Death is somewhat controversial, since in some areas there could have been mortality up to

\footnotetext{
${ }^{1}$ Clearly there is a larger body of historical and interdisciplinary research on the Black Death which I cannot cite here in full.
} 
$90 \%$ while other areas nearby could have escaped its ravages altogether [see the discussion in: 6, p. $245 \mathrm{ff}$.]. Many scholars believe that the population of Europe declined by one-third in the initial period of roughly 1346-1350 [26, p. 149-150]. A higher estimate is offered by Benedictow, according to whom mortality from plague reached $60 \%$ across Europe, with many communities wiped out completely [see 6, p. 380-384].

It will prove next to impossible to find similar direct evidence for the territories of the Golden Horde, but we can look for additional indirect evidence to give a broader picture. A few Arabic sources I have already cited elsewhere give some of the only estimates to be found in the sources for population dying during the outbreak of the Black Death in the territory of the Golden Horde. The account of Maqrīzi mentions depopulation in the steppe region prior to the arrival of the Black Death in the Middle East [24, ii/3, p. 773-774; and 13, p. 40-41]. Ibn alWardī writes that when the outbreak of disease arrived in the "land of Özbek" (bilād Uzbak) in Racab 747/October-November 1346, the villages and towns were emptied of their inhabitants. He also cites a report from a $q \bar{a} d \bar{l}$ in the Crimea estimating 85,000 dead [14, especially p. 448] $]^{2}$. Additional supporting evidence comes from the neighboring Russian territories to the west, with the Russian chronicles reporting numerous occurrences of plague in cities throughout Russia accompanied by a high rate of mortality [on the Black Death in Russia see: 50; 2; 22 , especially p. 55-61; and 21 ; and 3 , p. 12-15]. Indirect evidence is also provided by the spike in the number of gravestones bearing Nestorian Turkic inscriptions in the Syriac alphabet near Lake Isı-köl and by a parallel spike in the number of gravestones bearing Muslim Turkic inscriptions in the Volga Bulğarian in Arabic script in the Middle Volga region (see below).

Based upon everything we know about Europe and the Middle East in this period, the population lost must have been substantial - perhaps even extreme and it would not be until the mid- to late- $15^{\text {th }}$ centuries that we can see the outlines of a rebound in population. Nevertheless, it is not clear whether the population crisis of the $14^{\text {th }}-15^{\text {th }}$ centuries was strictly one of mortality (so death), or whether it also involved a question of factors affecting fertility [see 18, p. 2].

\section{Depopulation and political instability}

The most visible and dramatic result of the rapid depopulation associated with the Black Death was a disruption in the political system of the Golden Horde. The political system of the Golden Horde was based upon a system of political and marital alliances between a khan descended from Chinggis Khan and the leaders of four high-status tribes. The leaders of these four "ruling tribes", the four ulus beks (known in the time of the khanates of the Later Golden Horde of the $15^{\text {th }}-18^{\text {th }}$ centuries as the four qaraçı beys), formed a council of state involved in the selection and sometimes the removal of the Chinggisid khan, as well other matters of state [on this system see my: 46; 45; and 39]. The pattern of succession was originally based upon "collateral succession", with there being an expectation that the sons of the first generation descended from Chinggis Khan might rule in descending order based upon age. It is clear that in the succeeding generations this principle (or cultural expectation) based upon genealogy endured to one degree or

\footnotetext{
${ }^{2}$ For a reference to the original text of the Risāla in Ibn al-Wardī's Dīwān see: [14, p. 446 n. 16]; and the discussion of Ibn al-Wardī's works in my: [43, p. 455 n. 17].
} 
another, but in the Golden Horde it is clear that over time the tribal élite selected the khan without adhering strictly to the original principle of succession. As a result the line of succession appears to have shifted back and forth between lines of descent more than once. Within the tribes themselves there was also a hereditary leadership which appears to have passed from father to son (though it is not certain whether it was also based upon the same principle of collateral succession).

What would have been the result of the waves of plague in the territory of the Golden Horde beginning in the early 1340s? I must say that the most remarkable aspect of the political system of the Golden Horde in the 1340s-1350s was the unlikely extent to which it was actually politically stable. I would have expected that the political system would have collapsed sometime earlier during the 1340s$1350 \mathrm{~s}$. It is surprising for me that it was only after the death of Berdibek that the political order in the Golden Horde seems not just to have collapsed, but to have collapsed completely. Under what circumstances did both Canibek (d. 1357) and Berdibek (d. 1359) really die? Could they have fallen victim to the Black Death, as had Grand Duke Simeon several years earlier? It is hard to be sure, but what follows the death of Berdibek is the utter and complete collapse of political stability in the territories of the Golden Horde.

Until 1359 it appears that there was an orderly, stable, well-functioning political system in the territories of the Golden Horde. After 1359, with the collapsed of centralized authority, the only word one can use to describe what is going on in the territories of the Golden Horde is "anarchy". We see in the sources a succession of dozens of names in competition with one another such as Qulpa, Nevruz, Xızr, Temür Xoca, Ordu Melik, Keldibek, Murad, Pulad, Aziz, Abdullah, Hasan, and many, many others. Although the historiography is not clear on this, it is clear that while some of them are Chinggisids, others are tribal leaders vying for control of the Golden Horde in the west, so the ulus of Jöchi also known as the White Horde. (As is well known, the term "Golden Horde" is a later term, probably first used in the $16^{\text {th }}$ century, which becomes the most widely-used appellation for this state in modern scholarship.) At the same time figures from the eastern Blue Horde would also vie for control over the White Horde.

How can we explain the mechanism by which the Black Death had such an impact on the Golden Horde? The explanation for this lies in the system for orderly succession which forms the basis of the political organization of the Golden Horde. As noted above, the system of collateral succession formed the original basis of the method for determining succession among the first generations of Chinggisids after the death of Chinggis Khan. (Was the system of four ulus beks also underlying the earliest quriltays choosing the successors to Chinggis Khan? We will never know.) In succeeding decades it is clear that the same system of a khan plus four tribal leaders was involved in choosing and removing the Chinggisid khans of the Golden Horde. The most famous of these tribal leaders was Emir Noğay (d. 1299), though he was certainly not the only tribal leader about whom we have knowledge based on the sources. As waves of bubonic plague swept across the territories of the Golden Horde - but especially beginning in 1359 - the political system of the Golden Horde was disrupted. It appears that with the death of Berdibek - which coincided with a period of a number of years in which the Black Death was very active in the territories of the Golden Horde in the late 1350s-early 1360s - orderly succession became impossible. Trying to acquire objective, current information 
about the proper genealogical order of succession between Chinggisids was probably a hopeless task, since if one died before becoming khan his successors could lose the right to become khan. But who knew who was alive and who was dead? Each of the tribes also had its own internal leadership which must have faced the same crisis of leadership as the Chinggisids. As a result, with the breakdown of the political order, one person after another became selected and raised as khan, and either died or was overthrown. It is possible that the four chief tribes could no longer come together and function as a council of state. If the true power of the khan rested in the marital relationships between the khan and his offspring and the tribal leaders and their offspring, then this system was also disrupted for a long period of time.

As a result, the western ulus of Jöchi (the White Horde) fell deeper and deeper into anarchy. For some reason, the eastern ulus of Orda (the Blue Horde) seems to have been affected less by the Black Death (possibly because it was more nomadic), or else it simply was fortunate to have avoided the worst effects of successive waves of bubonic plague. Another possibility is that it experienced bubonic plague earlier and had already begun to recover demographically. What we can see is that they were in a position to dominate the western territories until those territories would begin to recover themselves in the mid- $15^{\text {th }}$ century.

In contrast, even though Grand Duke Simeon and other members of the ruling élite also died of the Black Death in Moscow in 1353, we cannot say that Muscovy and the other Russian principalities collapsed into anarchy. Quite the opposite. Since the basis of the state was estates, not genealogy, the foundation of the Russian principalities was not undermined. To the extent that depopulation characterized the Russian principalities from the second half of the $14^{\text {th }}$ century until the later $15^{\text {th }}$ century, the response was a centralization of political authority in the hands of fewer individuals, culminating ultimately in the "gathering of the Russian lands" under Ivan III (r. 1462-1505) [see especially the discussion in 2, p. 37-38]. This meant an increasingly stronger Russian state confronting a series of khanates in the $15^{\text {th }}-16^{\text {th }}$ centuries which were much smaller and weaker than the earlier Golden Horde prior to its collapse in 1359.

\section{Bubonic plague as biological warfare}

An episode connected with the arrival of the Black Death in Kaffa is often cited as the earliest example of the use of biological weapons in human warfare ${ }^{3}$. After reaching the land of Özbek and striking the cities of the Golden Horde, Yersinia pestis finally reached the Crimea, where the Italian commercial centers of the Crimea became the point of transmission of the Black Death to the Middle East and Europe. Italian merchants had been expelled from Tana (Azaq) in 1343, and they were besieged in the fortified city of Kaffa in 1343 and again in 1345-1346. According to one of the best known sources on the Black Death in Kaffa, the Historia de Morbo by Gabriele de' Mussis [see 17, p. 45-57; and the revised translation in 7, especially p. 17-18, 20], countless numbers of Tatars ("Tartars") and Saracens became afflicted in 1346 with an illness that resulted in sudden death. Large portions of these provinces, kingdoms, towns, and settlements were soon stripped of their inhabitants. The illness spread among the Tatars while they were

\footnotetext{
${ }^{3}$ On the development of a biological weapons program by the USSR utilizing smallpox and other biological agents (including Yersinia pestis), see: [1].
} 
holding under siege the Genoese colony of Kaffa (modern Feodosiya) in Crimea. At that time Kaffa also included Italian merchants who had fled Tana, an Italian colony on the mouth of the Don River. Unexpectedly thousands of Tatar soldiers began to die with the sudden swelling of the armpit or groin followed by a fever. Although the Tatar soldiers soon abandoned their siege, they began to place the corpses onto catapults and launch the bodies of their comrades who had fallen victim to the disease into the Genoese fortress of Kaffa. The Italians tried to dump as many of the bodies as possible into the Black Sea, but the rotting corpses filled the air with a stench and poisoned the water supply. Through their strong resistance, and perhaps due to the weakened state of the blockading army, the Genoese were able to lift the siege. Many Genoese then fled to Constantinople, taking the infection with them. I have outlined elsewhere the equally catastrophic effects of the Black Death on Anatolia and have proposed that the rise of the Ottoman Empire can be explained as a consequence of the Black Death [see my 42]. By 1347, the plague had reached Italy and Egypt from Constantinople. Soon the Black Death was raging throughout Europe and the Middle East.

\section{Economic crisis}

The sudden demographic crisis experienced by medieval European society had profound economic consequences [for an overview of these consequences see for example 5; 13, p. 255-280; 18, p. 39-57; and 9]. David Herlihy differentiates between short-term and long-term effects of the Black Death. He sees the shortterm repercussion as a shock which was very disruptive for regular economic life and interrupted routines of work and service ${ }^{4}$. Not only did the positions of those who died in a wide range of jobs and professions remain unfilled because of the deaths of the holders of these positions, others fled the town to the safety of the countryside - as in Boccaccio's Decameron - because people felt that they had no better option for saving themselves. This led to many towns being emptied of their population either because of the death of the population or flight. Those who remained behind sometimes refused to carry out their jobs, choosing instead to enjoy what they could of life before their turn to die arrived. In the countryside, as described by Guillaume de Machaut in 1349, because of a huge loss in the population (according to him, ninety-nine out of one hundred), there were not enough people remaining to tend to large farms, nor could sufficient laborers be found even at many times the pre plague salary. Fields went untilled, harvests remained ungathered, and herds were left untended, resulting in feral herds.

The high rates of mortality led to a sudden increase in the demand for certain professions. Gravediggers came into high demand. It is possible that prior to the arrival of the Black Death gravediggers in Florence may not have been paid, whereas after the arrival of the Black Death this was a paid job for which there was a high demand. Physicians were also in high demand to treat the ill, as were clergy to perform the rituals for the burial of the dead. As these professions were also losing many highly-trained members to epidemic disease, their ranks were joined by those who were less well trained or not trained at all. The Black Death similarly cut short the careers of many skilled artisans and craftsmen whose ranks needed to be replenished. Over the longer term, the skilled professions needed to bring in

\footnotetext{
${ }^{4}$ I refer the reader to [18, p. $40 \mathrm{ff}$.] for a more complete discussion and references to the sources.
} 
new members at a higher rate than before the Black Death, since the average length of one's career was now shorter. The rise in wages was a part of a general period of inflation, with grain prices rising until they finally begin to diminish after 1375 or 1395. Meanwhile, as wages rose, agricultural rents fell. Herlihy suggests that cheap land was substituted for expensive labor, leading for example to the expansion of pasturage at the expense of cultivated fields.

How might we apply these insights on the economic impact of the Black Death on medieval Europe to the history of the Golden Horde? We may safely assume that the sedentary regions of the Golden Horde also experienced a similar fate. The report estimating that 85,000 dead were dead in the Crimea suggests that the other towns of the Golden Horde also suffered shock from high rates of mortality. We have direct reports of other cities being struck, such as the report on the wave of 1364 originating in Saray [22, p. 57]. The kind of abundant detailed information available for medieval Europe is simply not available, however, for the Golden Horde. Yet there are some intriguing pieces of indirect evidence which fit the same pattern as for medieval Europe.

I have noted that flight from cities was a common response to outbreaks of plague in Europe. While in the Golden Horde we do not have direct evidence of flight, the curious case of Gülistan may pose indirect evidence for disruption caused by the Black Death. Mellinger believes that two types of Golden Horde coinage, the first minted in Saray in the year 746/1345-6 (and continued from $752 / 1351-2$ to $754 / 1353$ ) and the second minted in 749/1348-9, reflect the havoc caused by the Black Death in the Golden Horde. He also suggests that the establishment of Gülistan as a mint site in 752/1351-2 might have been a response to plague (a conclusion which both Mellinger and I have reached independently from each other) [see 27, especially p. 178-180]. In such a case Gülistan, which literally means "Rose Garden" (and the name of a popular romantic epic perhaps first translated into Turkic in the Golden Horde $)^{5}$ could be seen as a refuge parallel to Boccaccio's refuge in the countryside away from Florence.

The shock of the waves of Black Death in various years would have meant that, as elsewhere in Europe, the tending of fields, the harvesting of crops, and the taking care of herds could have been neglected. This would have affected the food supply of the urban population and perhaps of the nomads as well. It should not come as a surprise, therefore, that there are many reports of famine in this period in the Russian sources [see the table in 22, p. 58-61]. In the towns we can also expect that there would have been a need for more gravediggers, as well as pressure on healers and Muslim clerics. The number of craftsmen and artisans would have diminished greatly, too. While we do not have direct evidence for this, the fact that Volga Bulğarian ceased to be written as a literary language after 1358 (see below) suggests that the people who knew that language, or the scholars or clergy who could write the texts for the grave markers on which these inscriptions were written, or perhaps the stone carvers who would physically carve the stone grave markers were no longer in adequate supply. Perhaps with the demand for labor, which was in short supply, there were other urgent tasks which were tended to instead, or perhaps wages rose too high for people to be able to afford grave markers.

${ }^{5}$ This work is known from the translation by Seyf-i Serayi (a native of Saray) produced in Mamlūk Egypt in 1391, see: [47]. 
At the same time it is not clear whether a comparison of the Golden Horde with medieval Europe is more apt, or whether a comparison with medieval Egypt would be more appropriate. In Europe high wages resulted in cheap land and an increase in capital investment, as in oxen and seed being provided to agriculturalists to make it more attractive for laborers to cultivate the land. In contrast, medieval Egypt had a centralized landholding system with absentee landlords living in the cities. The Egyptian system could not adapt to massive depopulation and continued in crisis, while in England the localized rural landholding system had recovered fully by 1500 [see 9]. Was the Golden Horde system more like a centralized landholding system with absentee landlords, or was it a more localized landholding system? This is a question which requires further investigation.

Although we expect inflation, there are not many direct sources for this. Future researchers may be able to reconstruct the history of prices in the territory of the Golden Horde over the course of the $13^{\text {th }}-15^{\text {th }}$ centuries with a view to understanding the impact of the Black Death on prices. This will prove notoriously difficult, however, since the most abundant data is for the Italian colonies in the Crimea, where the markets - which were subject to influences from all over the Mediterranean - showed tremendous seasonal variation. According to Balard more is known about the grain trade after 1350, which makes it more difficult to evaluate the price of this commodity before and after the onset of the Black Death [on the commerce in wheat in the Black Sea region and elsewhere, see 4, ii, p. 749-768]. The idea of inflation in the territories of the Golden Horde is, however, supported by the numismatic evidence. I have proposed, with the assistance of my colleague Leonard Nedashkovsky, that the lighter standard for the silver dirham introduced as a part of the monetary reform of Toqtamıs in 782/1380-1381 (which was first put into effect in the Lower Volga region) can be considered direct evidence of inflation in this period [see 36].

We should not forget that one of the big differences between the states of Western Europe and the Golden Horde is that, even though it had significant amounts of agricultural exports to the Italian maritime republics, the territory of the Golden Horde was home to vast herds of horses, sheep, and other livestock which were tended by nomadic herders. It is certainly a principle that nomads are less susceptible to epidemic disease (though not immune to it), which is why we should not be surprised after the collapse of the urban centers of the Golden Horde (see below) there were still strong nomadic confederations. At the same time, if Western Europe is to serve as a guide, the decline in the rural agricultural population would have meant that less land was cultivated. This could have led to a greater exploitation of formerly-tilled agricultural land by herds of animals tended by nomadic herdsmen, or by local sedentarists for whom it was less labor-intensive to tend to herds of animals than to cultivate large fields now laying fallow (see below).

\section{Social crisis}

There is no question that in medieval Europe the Black Death created a major social crisis the likes of which had not been seen since the $6^{\text {th }}-8^{\text {th }}$ centuries ${ }^{6}$. As the ravages of the Black Death continued, people stopped treating the sick and dying as

\footnotetext{
${ }^{6}$ I refer the reader to $[18$, p. 59 ff.] for a more complete discussion and references to the sources.
} 
human beings. The sick were treated "no better than dogs" or were sent to pesthouses. There was a fear of transmission of disease from corpses and local administrations punished those who hid the sick. The dead became an overwhelming crisis, since towns and communities had difficulty dealing with the large numbers of dead or even the expense of digging their graves. The diminishing number of clergy meant that it was more difficult to offer the dead a proper burial. The numerous corpses ended up being treated no better than goat carcasses. In the longer term, the fact that in some parts of Europe the demographic structure of the population changed, meant that an unusual number of younger persons and older persons were left alive. This meant that the ratio of dependents to productive workers increased, putting additional pressure on the main providers in the family. Clearly some children must have been orphaned, while some elderly must have been left without family members to care for them.

It is nearly impossible to document this range of issues for the territories of the Golden Horde. It is clear, as with the report from the Crimea, that there were large numbers of dead. The "weaponization" of the dead by the Mongols (see above) seems to fit with the notion of corpses being treated like goat carcasses, but of course this may reflect more on Mongol military tactics than on their becoming inured to the death of civilians around them. As noted above in the section on the economy, the end of gravestones with inscriptions in Volga Bulğarian could also be linked to the inability of the Muslim population in the Middle Volga region to properly bury its dead in the way it had been accustomed. At a higher level, namely the level of the élite, the anarchy in the traditional political system of the Golden Horde meant that the lines of the ruling families and the family lines of the tribal leadership were disrupted, as we see in the sources (see above).

\section{Urbanization and deurbanization}

Although medieval Europe experienced a substantial decline in its population as a result of the Black Death, we do not speak of the deurbanization of medieval Europe, even though it appears that many villages were abandoned following the Black Death [see 49, p. 52; and https://en.wikipedia.org/wiki/Abandoned_village]. Clearly villages, towns, and urban centers were characteristic features of Europe's economy based upon a sedentary way of life and agriculture. In the Eurasian steppe zone, however, it is clear that before the modern era this zone was not characterized by villages, towns, and urban centers; rather this zone was characterized by pastoral nomadism. Urban centers were characteristic of the Crimea, Khwarezm, and the Middle Volga region, but the grasslands of the steppe in which nomadic confederations dominated probably could not afford sufficient security for the establishment of agricultural settlements. It is only with the expansion of the Russian Empire in the modern period that we see the complete agricultural colonization of this zone.

I argue elsewhere that the establishment of the Mongol World Empire created a secure environment of merchants to travel across Eurasia. This is very clear from the account of William of Rubruck, for example [28]. The Golden Horde also provided security for the trade network known popularly in modern times as the "Silk Road". The communication network of the Mongol World Empire (cam) required a regular network of manned stations for changing horses [see 29, p. 103107]. Merchants also had a need for regular stations or caravanserais, too. This 
probably led to the development of a series of towns along transportation and trade routes. With the ever-increasing volume in trade the Golden Horde élite beginning with Batu Khan began to establish fixed cities at the southern and northern edges of the annual migration route of his flocks, Saray Batu and probably Ükek, respectively [see my 38]. Saray Batu and later Saray Berke became important political, commercial, and cultural centers. An important description of various urban centers in the Golden Horde in the 1330s is provided by Ibn Bațtututa, less than a decade before the initial outbreaks of bubonic plague on the territories of the Golden Horde in the early 1340s. With the increase in the export of grain to the Italian maritime republics there was an expansion of agricultural production, probably including in the steppe zone around Ükek, thanks to the security provided by the Golden Horde. This necessarily meant an increase in the number of agricultural settlements in this zone. Nedashkovsky also studies the towns established in the region around Ükek (a suburb of present-day Saratov) [55; 30; and 54]. This is also seen from a map of settlements established in the $13^{\text {th }}-14^{\text {th }}$ centuries offered by Egorov [51, p. 232-233 (maps are between these pages)].

Given the paucity of sources for Golden Horde following the outbreak of the Black Death, we can only state that there is direct and indirect evidence for the Black Death visiting Khwarezm, the Crimea, Saray, Volga Bulğaria, and more generally the towns and cities of the Golden Horde, as noted elsewhere. It is difficult to be more specific, since our sources do not offer any more information about a wide range of settlements, towns, and cities in the steppe zone. It is clear that settlements, towns, and cities continued to exist in the traditional areas of sedentary habitation. In the Middle Volga region, however, we do see is that 70 years after the apparent decline or demise of Volga Bulğaria ca. 1358 (judging by the end of the Volga Bulğarian inscriptions, see below), the Khanate of Kazan is established almost 100 $\mathrm{km}$ to the north of the site of the town known today as Bulgar. It is quite possible that this is a case of the abandonment of the site of the former Volga Bulğarian town as a political center for the region. It is not to be excluded that the reason for this was that it was somehow "marked" as a place of death. In this case it would be comparable to the settlements abandoned in medieval Europe.

In the steppe zone, itself, we can probably speak of destruction and deurbanization, too. The great $17^{\text {th }}$ century Ottoman traveler Evliya Çelebi offers us a survey of the towns he visited during one of his visits to the territories of the former Golden Horde in 1664 [16, vii, p. 473 ff.; and 15, vii, p. 368 ff.]. He often repeats that Toqtamış had leveled whichever town he was describing at the moment [16, vii, p. 479, 485, 488, 490, 492, 522, 566; and 15, vii, p. 371, 376, 378, 380, 402, viii, 23]. In his account Saray (probably Saray Batu, given its proximity to the Caspian Sea) is still not very developed (hâlâ o kadar imar değildir) and is a poor town of 9,000 ill-fated houses of wood with (thatched) rooves of rushes and reeds (hepsi dokuz bin tahta, saz ve kamış ile örtülü uğursuz evlerden ibarettir). Moreover they speak so many different languages that they must communicate through interpreters, which also suggests that many of them had arrived there only recently [16, vii, p. 479-480; and 15, vii, p. 372]. We also learn from his description that significant numbers of nomads or semi-nomads live among what Evliya Çelebi refers to as the "ruins" (harabeler) of this region. The general impression one gets is that - considering that this is a period of time in which the population has already recovered significantly - it is not a robust urban population. 
Even if we may question at times the reliability of Evliya Çelebi's description, the extent to which the urban tradition of this region declined compared to the time of the visit of Ibn Batțūta in the 1330s or indeed was disrupted is certainly a topic which merits further study based upon the later sources.

\section{Population pressure and migration}

With the substantial depopulation across the territories of the Golden Horde (which may not have been uniform, of course), we can see several phenomena related to the movement of people to areas which were suddenly depopulated, or at least politically and militarily weakened. The first example can be the expansion by Lithuania to the south as far as the Black Sea. As Pelenski has demonstrated (though without mentioning bubonic plague), Lithuania expanded its territories dramatically in the $2^{\text {nd }}$ third of the $14^{\text {th }}$ century. It expanded into Belorussia and five Ukrainian lands (the conquest of Chernigov in three stages beginning in 1345, Siveria, the conquest of Kiev and the Kievan land by 1361-1363, Pereyaslavl following Kiev, and major parts of Podolia in the first half of the 1360s) [32, especially p. 308]. Lithuania scored a major victory over the forces of the Golden Horde at the Battle of the Blue Water (Sinyaya voda) in 1362 [32, p. 309-311]. Lithuania even established control over the northern coast of the Black Sea under Witold (r. 1392-1430) [32, p. 318]. This territorial expansion corresponds to the period of the ravages of the bubonic plague, which certainly led to substantial depopulation and political instability in the period which Pelenski calls the "Time of Troubles" in the Golden Horde following the death of Canıbek Khan. It is possible that the Black Death may not have affected Lithuania as profoundly as it did the territories of Russia and the Golden Horde ${ }^{7}$. This is a topic meriting further consideration.

It is also possible that the territories of the eastern half of the Golden Horde (so the Blue Horde) were not affected as profoundly as the western territories (so the White Horde), or possibly that the eastern territories began to recover more rapidly. The now-weakened Golden Horde begins to experience a series of attacks from the east as Urus Khan and then later Toqtamış lead campaigns against the territories of the western half of the Golden Horde [for a discussion of the sources for this section see my 45, p. 179-204; 52, p. 690; 41, p. 113-114; and 39, p. 16-17]. Let us leave aside for the moment the question of the origins of Toqtamıs. As I have argued elsewhere, we see from a later source that when Toqtamıs is playing the role of de facto or de jure ruler in the western territories in the 1380s and part of the 1390s, he is supported by a confederation of four "ruling tribes" consisting of the Şirin, Arğın, Barın, and Qıpçaq. It is significant that these four tribes migrated to this territory at the end of the $14^{\text {th }}$ century along with Toqtamıs. The same four tribes will later form the basis of the xanates of the Crimea, Kazan, and part of the xanate of Kasimov. In order to appreciate the significance of this information, we should consider that according to one source the four tribes of the nomadic "Great Horde" of the $15^{\text {th }}$ century were the Q1yat, Mangit, Sicivut, and Qongrat. If we may consider the nomadic Great Horde to be the last remnant of the earlier Golden Horde (more accurately, the western White Horde) and its direct continuation, then these four tribes (the Q1yat, Mang1t, Sicivut, and Qongrat) must also have been the earlier tribes of the western territories of the Golden Horde (so the White Horde).

\footnotetext{
${ }^{7}$ Benedictow suggest that the Black Death may have spread more slowly in the Baltic region, see: [6, p. 209-210].
} 
This allows us a second example of population moving to an area depopulated by the bubonic plague [cf. 26, p. 170-171].

The third and final example I would suggest would be the later movement of Kipchak Turkic-speaking population into the Middle Volga region. If we may take the Volga Bulgarian inscriptions as any indication, the dominant population of the Middle Volga region spoke Volga Bulğarian, which belongs to the Western or Bulğar branch of the Turkic languages whose sole modern relative is Chuvash. I have noted elsewhere that it is also possible that Volga Bulğarian served the purpose of a "religious" language for speakers of Kipchak Turkic languages and perhaps even speakers of Turkic languages belonging to other branches of the Turkic languages [44]. (We will never know for sure.) The fact that over the course of the $15^{\text {th }}-16^{\text {th }}$ centuries we see the rise of a strong Kipchak Turkic-speaking population, based upon the Kipchak Turkic language (Old Kazan Tatar) used in the gravestones from this period and the official diplomatic correspondence of the Khanate of Kazan, we can see that there was an in-migration of Kipchak Turkic population, probably including nomadic Noğays. Not only would this be our third example of a population moving into a region depopulated by bubonic plague, it can also serve as an example of the phenomenon described by Herlihy of the expansion of pasturage at the expense of cultivated fields. Of course, any nomadic population moving to the Middle Volga region eventually sedentarized.

\section{Cultural and technological regression}

As I have argued elsewhere, I believe that we see the end of several Turkic literary languages in the mid- $14^{\text {th }}$ century because of the Black Death. At the far eastern edge of the territories of the Golden Horde, around Lake Isıq-köl there was a community of Christian Turks using the Syriac alphabet to write funerary inscriptions. The gravestones of the Nestorian gravesites around this site record that an outbreak of plague took place there in 1338-1339 [for a description of these inscriptions and further bibliography see 48]. During these two years there is an unusually high number of gravestones, with some of the gravestones recording that the person buried there had died of plague [see 58, especially p. 305-305; $12 ; 11$, p. 31-38]. There is a second peak in the number of gravestones in 1341, which probably reflects a second wave of plague, even though this fact is not mentioned in the gravestones [this is pointed out by 11, p. 39-40]. I have proposed that the fact that the Syriac Turkic inscriptions largely disappear after this period is a result of plague [see my 44, especially p. 161-162]. The corpus described by Xvol'son for the years 1226-1373 included at least 37 inscriptions for the period 1338-1339, while for the period 1342-1373 there was only one recorded for 1347, after which the next and final inscription is from 26 years later [see 58, p. 306] ${ }^{8}$. According to Thacker, the earliest of these inscriptions dates from 1186 and the last from 1345 [48, p. 99]. Taking more recent finds into account, Klein states that the gravestones date from 1250-1342, except in Almaliq (along the Kazakh-Chinese border in the region of Taldıqorğan), where the last inscriptions are from the 1370s [20, especially p. 214].

The second language to disappear as a result of the Black Death was Volga Bulğarian, a Western Turkic language whose sole surviving relative is Chuvash. Volga Bulgarian is known from the inscriptions on gravestones from the Middle

\footnotetext{
${ }^{8} \mathrm{~A}$ large portion of the corpus is undated.
} 
Volga region beginning in the $13^{\text {th }}$ century [on these inscriptions see 35 ; and 57 . On the relationship between Volga Bulgarian and Chuvash see also 34, p. 13-123; and 33]. The earliest inscription in Volga Bulğarian in the city of Bulğar itself dates from 1271, while the last ones date from 1356 [53, p. 120]. In addition to inscriptions in Volga Bulğarian there were also funerary inscriptions in a Standard Turkic dialect which may be considered as a precursor of the modern Kazan Tatar language in the Middle Volga region [see 56, p. 5-15] $]^{9}$. In a parallel to the situation a number of years earlier near Lake Isıq-köl, there is a peak in the number of gravestones with inscriptions in Volga Bulğarian and Standard Turkic in 1357 and $1358^{10}$. After 1358 there are no new inscriptions or any other text written in Volga Bulğarian, with only a limited number of inscriptions in Standard Turkic in the years following this date [see for example the two inscriptions dated 1382 and 1399 in 56, nos. 18, 19]. There is furthermore a general decline in the number and variety of gravestones in this region after 1358 [see the discussion in 53, p. 120-126].

I will offer one final example, namely the disruption in the literary language of the Golden Horde after 1358. The last work in the literature of the Golden Horde was the Nehc ül-feradis. Already in the $19^{\text {th }}$ century Şihabeddin Mercani described a manuscript of the Nehc ül-feradis (now lost) copied in Saray in 749/1358. That manuscript attributed the work to one Mahmud born in Bulğar, who found refuge in Saray, and whose family name (nisba), Kerderī, linked him with the city of Kerder in Xwarezm. Another manuscript says that the author died three days after March 25, 1360. The manuscript edited by Eckmann et al. was completed on 6 Cumādā I, 761/March 25, 1360, indicates the various sources on which it was drawn, and finally refers to the author as Muhammad b. Muhammad b. Xusrev elXorezmi [8, p. 95; and 31, p. 309. See also 25, p. 8]. After the death of this author in 1360 , we do not see another literary or religious work produced in the language of the Golden Horde, only funerary inscriptions. Instead, we do not see new literary or religious works until those written in Chaghatay and produced in Central Asia in the early $15^{\text {th }}$ century.

All of this may be taken as evidence to suggest that, as is the case of the Latin literary language in Europe, bubonic plague led technological regression disrupting the development of multiple Turkic literary languages in the territories of the Golden Horde [I have argued this in 40, i, p. 501-507].

\section{Increase in religiosity}

The next result of the Black Death which I will consider here is increased religiosity. People living in the time of plague were frightened by the arrival of plague as an indication of God's displeasure with them. They concluded that they were poor Muslims and sought to atone for their sins. Some people gave away their possessions or performed pious acts. This was equally true of the Muslim Turks of the Golden Horde. As noted (above), a work of Islamic Turkic religious literature was produced in the Golden Horde in 1358 (a plague year) with the Arabic title Nehc ül-feradis and bearing the Turkic subtitle Uş̧maxlarnıı açuq yoll, meaning 'The Clear Path to Heaven'. This work is a handbook of the Islamic religion, with

\footnotetext{
${ }^{9}$ For a map of the distribution of both kinds of inscriptions see: [57, p. 21].

${ }^{10}$ These eight inscriptions are: [35, 1357: nos. 24, 25, 52; 57, 1357: no. 23, and 1358: nos. 24, 25; and 56, 1357: nos. 16, 17]. Cf. [57], in which no. 26 is read as "1361?", while the same inscription is read by $[35$, no. 26$]$ as " $1353-4$ ?".
} 
the title suggesting that if one reads this book (and, perhaps, we might add, if one writes such a book), one is guaranteed entry to heaven. Why else would a devout Muslim be concerned unless there is clear evidence of God's impending punishment? [for parallel evidence from Anatolia see 42, p. 268]. It also appears that this work was also copied just before the author himself died. I would argue the production of such religious literature and its copying were pious acts performed to regain God's favor in order to ward off disease. This is buttressed by the subtitle of the work: Why else would they be concerned with getting to heaven? There is at least one parallel example to this in Anatolia as well, namely Süleyman Çelebi's early $15^{\text {th }}$ century religious poem in honor of the birth of the Prophet Muhammad (mawlid) entitled Vesilet ün-necat or "Path to Salvation"

There was yet another consequence of the Black Death for religion and religiosity, namely the dramatic strengthening of the relationship between the ruler and the religious class. Of course it is the case that earlier rulers such as Özbek Khan already had a close relationship with the religious élite [19, ii, p. $482 \mathrm{ff}$.]. Later, upon the collapse of the Golden Horde state, the clear lines of succession in the dynastic and tribal leadership as well as well as the four-bey system were disrupted. Many individuals competed for the right to be elevated as xan. From this time on, descent from Chinggis Khan was no longer sufficient to guarantee political legitimacy. The leaders of Sufi orders, which had been active throughout the $13^{\text {th }}-14^{\text {th }}$ centuries, were now in a position to offer Islam as a second source of political legitimacy. The Black Death ushered in a new era in which Chinggisid political leaders were now allied even more closely with Islamic religious leaders. Individual Sufi shaykh offered candidates for khan Islamic legitimacy to supplement their Chinggisid descent. In return, a candidate for xan, once successful, could offer the Sufi şeyx who supported him and his order tremendous prestige and, as in Central Asia, wealthy estates. In this regard, the Black Death was certainly a factor in the dramatic increase in the importance of Sufi orders after the second half of the $14^{\text {th }}$ century.

\section{Rise in population after the Black Death}

Even though the Black Death evidently contributed to large-scale depopulation in the territories of the Golden Horde, eventually the population would begin to grow again. In Europe this recovery was certainly in evidence by the second half of the $15^{\text {th }}$ century. For example, Cohn notes a surge in the number of surviving publications (incunabula) in Europe in the 1470s, which we may take as a possible reflection of the rising population in this period [see 18, p. 11]. Perhaps we can see in the foundation of the Khanate of Kazan in the late 1430s, the Crimean Khanate in the 1440s, the Khanate of Kasimov in the 1450s, and the Siberian Khanate in Tümän at the end of the $15^{\text {th }}$ century as indirect evidence of sufficient recovery of the population to make governance of isolated regions of the western territories of what was once a vast state possible. After all, when Uluğ Muhammad moved north to Kazan, he needed to also take a certain number of forces with him, which would only be possible with a rise in the population. We need to look for more evidence of a rising population by the mid- $15^{\text {th }}$ century in the territories of the Later Golden Horde. The Kipchakization of the Middle Volga region must also be seen as a

${ }^{11}$ See my forthcoming articles on the Turkish mevlid tradition and its later history among the Muslim Turks of the Russian Empire. 
result of Kipchak Turkic speakers migrating into the region after the reversal of the decline in population (see above), though we may certainly expect that the decline in the nomadic population was less severe compared to the decline in the sedentary population.

\section{Conclusion}

It is clear that the primary sources for the territories of the Golden Horde in the $14^{\text {th }}-15^{\text {th }}$ centuries do not provide the kind of detailed on the Black Death and its political, economic, social, and cultural consequences which we find in ample supply for Europe. Even the Middle East has much more detailed information than we can find for the territories of the Golden Horde. Nevertheless, I hope that I have been able to show that the political, economic, social, and cultural transformations in these territories from the mid- $14^{\text {th }}$ to the mid- $15^{\text {th }}$ centuries are consistent with what we might expect to find from a territory and population living through successive waves of bubonic plague. Regarding some of the consequences I rely more on speculation than hard data, to be sure. It is my firm conviction, however, that once we become aware of the Black Death and its well-documented consequences for Europe and the Middle East in this same period, it becomes possible to find some direct and substantial amounts of indirect evidence for studying the shadow cast by the Black Death over this state and its population. If we take these and other theorized consequences to be an agenda for research, I believe that future researchers will be able to marshal much more evidence in support of the consequences outlined here.

\section{REFERENCES}

1. Alibek K., Handelman S. Biohazard: The Chilling True Story of the Largest Covert Biological Weapons Program in the World - Told from Inside by the Man Who Ran It. New York, Random House, 1999. xi +319 p.

2. Alef G. The Crisis of the Muscovite Aristocracy: A Factor in the Growth of Monarchical Power. Forschungen zur osteuropäischen Geschichte. Bd. 15. Wiesbaden, Harrassowitz, 1970, pp. 15-58 [reprinted in Rulers and Nobles in Fifteenth-Century Muscovy (London, 1983), V]

3. Alexander J.T. Bubonic Plague in Early Modern Russia. Public Health \& Urban Disaster. Baltimore, Johns Hopkins University Press, 1980. xvii +385 p.

4. Balard M. La Romanie génoise (XII - début du XV siècle), i-ii. Rome, École française de Rome, 1978. (In French)

5. Bean J.M.W. The Black Death: The Crisis and its Social and Economic Consequences. The Black Death: The impact of the $14^{\text {th }}$-century plague. Papers of the $11^{\text {th }}$ annual conference of the Center for Medieval \& Early Renaissance Studies, ed. Daniel Williman. Binghamton, NY, Center for Medieval and Early Renaissance Studies, 1982, pp. 23-38.

6. Benedictow O.J. The Black Death, 1346-1353: The Complete History. Woodbridge, Suffolk, Boydell, 2004. xvi +433 p.

7. The Black Death, ed.-trans. Rosemary Horrox, Manchester Medieval Sources Series. Manchester-New York, Manchester University Press, 1994, pp. 14-26.

8. Bombaci A., trans. I. Mélikoff, Histoire de la littérature turque. Paris, C. Klincksieck, 1968. viii +437 p. (In French)

9. Borsch S.J. The Black Death in Egypt and England: A Comparative Study. Austin, University of Texas Press, 2005. xii +195 p. 
10. Campbell B.M.S. Before the Black Death: Studies in the 'Crisis' of the Early Fourteenth Century. Manchester, Manchester University Press, 1992. viii +232 p.

11. Chwolson D. Syrisch-nestorianische Grabinschriften aus Semirjetschie. Neue Folge. St. Pétersbourg, Académie Impériale des Sciences, 1897. 62 p. (In German)

12. Chwolson D. Syrisch-nestorianische Grabinschriften aus Semirjetschie. Mémoires de l'Académie Impériale des sciences de St.-Pétersbourg. Vol. VII, 37:8. St.-Pétersbourg, Académie Impériale des Sciences, 1890, pp. 129-130. (In German)

13. Dols M. The Black Death in the Middle East. Princeton, Princeton University Press, 1977. xvii $+390 \mathrm{p}$.

14. Dols M. Ibn al-Wardī's Risālah al-naba' can al-waba', A Translation of a Major Source for the History of the Black Death in the Middle East. Near Eastern Numismatics, Iconography, Epigraphy and History. Studies in Honor of George C. Miles, ed. D.K. Kouymjian. Beirut, American University of Beirut, 1974, pp. 443-455.

15. Evliya Çelebi, trans. Seyit Ali Kahraman and Yücel Dağlı. Günümüz Türkçesiyle Evliya Çelebi Seyahatnamesi. Istanbul, Yapı ve Kredi Yayınları, 2011. (In Turkish)

16. Evliya Çelebi Seyahatnamesi, ed. Mehmed Zillioğlu, i-x. Istanbul, Üçdal Neşriyat1, 1985. (In Turkish)

17. Henschel A.W. Document zur Geschichte des schwarzen Todes. Repertorium für die gesammte Medicin, ed. Heinrich Haeser, ii. Jena, Druck und Verlag von Friedrich Mauke, 1841. (In German)

18. Herlihy D., Cohn S.K. Jr. The Black Death and the Transformation of the West. Cambridge, MA, Harvard University Press, 1997. 117 p.

19. Ibn Batțūta, Riḥla, trans. H.A.R. Gibb, The Travels of Ibn Battututa, A.D. 13251354, i-iii. Works Issued by the Hakluyt Society. Cambridge, 1958-1971.

20. Klein W. Syriac Writings and Turkic Language According to Central Asian Tombstone Inscriptions. Hugoye: Journal of Syriac Studies. Vol. 5:2. Washington, DC, Syriac Computing Institute, 2002, pp. 213-223.

21. Langer L.N. Plague and the Russian Countryside: Monastic Estates in the Late Fourteenth and Fifteenth Centuries. Canadian-American Slavic studies. Vol. 10. Pittsburgh, Pa., University Center for International Studies, University of Pittsburgh, 1976, pp. 351-368.

22. Langer L.N. The Black Death in Russia: Its Effects Upon Urban Labor. Russian History. Vol. 2. Leiden, Boston, Brill, 1975, pp. 53-67.

23. Little L.K. Plague Historians in Lab Coats. Past and Present. Vol. 213. Oxford, Past and Present Society, 2011, pp. 267-290.

24. Maqrīzì. As-sulūk li-macrifat duwal al-mulūk, ed. M.M. Ziada, Cairo, 1958. (In Arabic)

25. Mäxmüd äl-Bolgari, ed. Fänüzä Nurieva, Nähcel-färadis. Kazan, 2002. (In Tatar)

26. McNeill W.H. Plagues and Peoples. Garden City, N.Y., Anchor Press, 1976. viii + 369 p.

27. Mellinger G. The Silver Coins of the Golden Horde: 1310-1358. Archivum Eurasiae Medii Aevi. Vol. 7. Wiesbaden, Otto Harrassowitz Verlag, 1987-1991, pp. 153-211.

28. Mission to Asia, trans. A Nun of Stanbrook Abbey, ed. C. Dawson. London, 1955/Toronto, University of Toronto Press in association with the Medieval Academy of America, 1980. xxxix $+246 \mathrm{p}$.

29. Morgan D. The Mongols. New York, Basil Blackwell, 1987. xviii +238 p.

30. Nedashkovsky L.F. Ukek: The Golden Horde city and its periphery. An analysis of the written, numismatic and artefactual evidence for the city of Ukek and the Jochid state on the Volga, $12^{\text {th }}$ to $15^{\text {th }}$ centuries. British Archaeological Reports S1222. Oxford, England: Archaeopress, 2004. i 253 p.

31. Nehcü'l-ferādīs. Uş̧tmahlarning açuq yolı (Cennetlerin açık yolu), ed. János Eckmann et alia, ii: Metin, Türk Dil Kurumu Yayınları 518. Ankara, Atatürk Kültür, Dil ve Tarih Yüksek Kurumu, 1995. x + 312, $444+$ xiv p. (In Turkish) 
32. Pelenski J. The Contest between Lithuania-Rus' and the Golden Horde in the Fourteenth Century for Supremacy over Eastern Europe. Archivum Eurasiae Medii Aevi. Vol. 2. Wiesbaden, Otto Harrassowitz Verlag, 1982, pp. 303-320.

33. Róna-Tas A. The Periodization and Sources of Chuvash Linguistic History. Chuvash Studies, ed. A. Róna-Tas. Budapest, 1982, pp. 113-169.

34. Róna-Tas A. Bevezetés a csuvas nyelv ismeretébe. Budapest, Tankönyvkiadó, 1978. 480 p. (In Hungarian)

35. Róna-Tas A., Fodor S. Epigraphica Bulgarica: a volgai bolgár-török feliratok. Studia Uralo-Altaica. Vol. 1. Szeged, Universitatis Szegediensis de Attila József nominata, 1973. 189 p. (In Hungarian)

36. Schamiloglu U., Nedashkovsky L. Coins Tell Their Own Story: Numismatic Evidence and the History of the Golden Horde and the Later Golden Horde. Proceedings of the $2^{\text {nd }}$ International Conference on the Golden Horde and Its Successor States (Istanbul, 22-24 April 2005), ed. Timur Kocaoğlu and Uli Schamiloglu (forthcoming).

37. Schamiloglu U. The Plague in the Time of Justinian and Central Eurasian History: An Agenda for Research. Central Eurasia in the Middle Ages. Studies in Honour of Peter B. Golden, ed. Osman Karatay and István Zimonyi, Turcologica 104. Wiesbaden, Harrassowitz Verlag, 2016, pp. 293-311.

38. Schamiloglu U. The Rise of Urban Centers in the Golden Horde and the City of Ükek. Proceedings of the conference on the Historical and Archeological Heritage of the Golden Horde on the Territory of Saratov's Volga Region: Uvek - Past, Present and Future. Saratov, Russia, June 2015.

39. Schamiloglu U. The Origins of Kazakh Statehood: From the Golden Horde to the Kazakh Khanate. Qazaq xandı̆̆ını qurıluını 550 jıldı̆̆ına oray uyımdastırllğan "Qazaq xandığı: tarix, teoriya jäne bügingi kün” attı xalıqaralıq ğllımi-teoriyalıq konferentsiya Materialdarı. 5-6 mausım 2015 jll, Almatı qalası. Almatı, Qazaq universiteti, 2015, pp. 15-18.

40. Schamiloglu U. Ortaçağ Dillerinden Modern Dillere: Avrupa ve Türk Dünyasında Yeni Edebi Dillerin Varlığa Gelmesi. IV. Dünya Dili Türkçe Sempozyumu Bildirileri. 2224 Aralık 2011, Muğla, i-ii, ed. Mehmet Naci Önal. Ankara, 2012. (In Turkish)

41. Schamiloglu U. The Black Death in the Golden Horde and the Later Golden Horde and its Consequences. Natsional'naya istoriya tatar: Teoretiko-metodologicheskie problem [National History of the Tatars: Theoretical and Methodological Problems]. Vypusk 2, Bibliotheca Tatarica. Kazan', Institut istorii AN RT, 2011, pp. 98-117.

42. Schamiloglu U. The Rise of the Ottoman Empire: The Black Death in Medieval Anatolia and its Impact on Turkish Civilization. Views From the Edge: Essays in Honor of Richard W. Bulliet, ed. Neguin Yavari, Lawrence G. Potter, and Jean-Marc Oppenheim. New York, Columbia University Press, 2004, pp. 255-279.

43. Schamiloglu U. Preliminary Remarks on the Role of Disease in the History of the Golden Horde. Central Asian Survey. Vol. 12:4. Oxford, Oxford Microform Publ., 1993, pp. 447-457.

44. Schamiloglu U. The End of Volga Bulgarian. Varia Eurasiatica. Festschrift für Professor András Róna Tas. Szeged, Dep. of Altaic Studies, 1991, pp. 157-163.

45. Schamiloglu U. Tribal Politics and Social Organization in the Golden Horde. Ph.D. dissertation. Columbia University, 1986. 286 p.

46. Schamiloglu U. The Qaraç1 Beys of the Later Golden Horde: Notes on the Organization of the Mongol World Empire. Archivum Eurasiae Medii Aevi. Vol. 4. Wiesbaden, Harrasowitz, 1984, pp. 283-297.

47. Seyf-i Sarayi, ed.-trans. A. Bodrogligeti, A Fourteenth Century Turkic Translation of Sa 'dī's Gulistān (Sayf-i Sarāȳ̄'s Gulistān bi't-turkī). Budapest, 1969.

48. Thacker T.W. A Nestorian Gravestone from Central Asia in the Gulbenkian Museum, Durham University. The Durham University Journal. Vol. 59. Durham, Durham University Geographical Society, 1967, pp. 94-107. 
49. Wunderli R. Peasant Fire: The Drummer of Niklashausen. Bloomington. Indiana University Press, 1992. xii +156 p.

50. Derbek F.A. Istoriya chumnykh epidemiy v Rossii s osnovaniya gosudarstva do nastoyashchego vremeni [The History of Plague Epidemics in Russia since the State Foundation to the Present]. Seriya doktorskikh dissertatsiy, dopushchennykh $k$ zashchite $v$ Imperatorskoy voenno-meditsinskoy akademii v 1904-1905 uchebnom godu [A Series of Doctoral Dissertations Accepted for Defense in the Imperial Military Medical Academy in the 1904-1905 academic year]. No. 14. St. Petersburg, 1905, pp. 14-25. (In Russian)

51. Egorov V.L. Istoricheskaya geografiya Zolotoy Ordy v XIII-XIV vv. [Historical Geography of the Golden Horde in the $13^{\text {th }}-14^{\text {th }}$ centuries]. Moscow, Nauka Publ., 1985. 245 p. (In Russian)

52. Istoriya Tatar s drevneyshikh vremen v semi tomakh: III. Ulus Dzhuchi (Zolotaya Orda). XIII-seredina $X V v$. [History of the Tatars since the Ancient Times in Seven Volumes. Vol. III: The Ulus of Jochi (Golden Horde). $13^{\text {th }}$ - middle of the $15^{\text {th }}$ centuries]. Kazan, Sh.Marjani Institute of History of Tatarstan Academy of Sciences, 2009. 1056 p. (In Russian)

53. Mukhametshin D.G., Khakimzyanov F.S. Epigraficheskie pamyatniki goroda Bulgara [Epigraphic Monuments of the Town of Bolghar]. Kazan, Tatarskoe knizhnoe Publ., 1987. 128 p. (In Russian)

54. Nedashkovskiy L.F. Zolotoordynskie goroda Nizhnego Povolzh'ya i ikh okruga [The Golden Horde Towns of the Lower Volga Region and Their Districts]. Moscow, Vostochnaya literatura Publ., 2010. 351 p. (In Russian)

55. Nedashkovskiy L.F. Zolotoordynskiy gorod Ukek i ego okruga [The Golden Horde Town of Ukek and Its Districts]. Moscow, Vostochnaya literature Publ., 2000. 224 p. (In Russian)

56. Khakimzyanov F.S. Epigraficheskie pamyatniki Volzhskoy Bulgarii i ikh yazyk [Epigraphic Monuments of the Volga Bulgaria and Their Language]. Moscow, Nauka Publ., 1987. 191 p. (In Russian)

57. Khakimzyanov F.S. Yazyk epitafiy Volzhskikh Bulgar [Language of the Volga Bulgars' Epitaphs]. Moscow, Nauka Publ., 1978. 205 p. (In Russian)

58. Khvol'son D. Predvaritel'nye zametki o naydennykh v Semirechenskoy oblasti siriyskikh nadgrobnykh nadpisyakh [Preliminary Notes on the Syriac Funerary Inscriptions Found in the Semirechensk Area]. Zapiski Vostochnogo Otdeleniya Imperatorskogo Russkogo Arkheologicheskogo Obshchestva [Notes of the Oriental Division of the Imperial Russian Archaeological Society]. No. 1. St. Petersburg, 1886, pp. 84-109, table (following 160), 217-221, 303-308. (In Russian)

About the author: Uli Schamiloglu - Ph.D. (History), Professor, Department of German, Nordic, and Slavic, University of Wisconsin-Madison, ORCID: http://orcid.org/0000-0003-0658-1267 (1220 Linden Drive, Madison, WI 53706, USA). E-mail: uschamil@wisc.edu 


\title{
ВЛИЯНИЕ ЧЕРНОЙ СМЕРТИ НА ЗОЛОТУЮ ОРДУ: ПОЛИТИКА, ЭКОНОМИКА, ОБЩЕСТВО, ЦИВИЛИЗАЦИЯ
}

\author{
Юлай Шамильоглу \\ Висконсинский университет в Мадисоне \\ Мадисон, США \\ uschamil@wisc.edu
}

\begin{abstract}
Цель исследования: данное исследование представляет обзор политических, экономических, социальных и культурных последствий Черной Смерти (эпидемии бубонной чумы, вызванной бактерией Yersinia pestis) на территориях Золотой Орды в $\mathrm{XIV}-\mathrm{XV}$ веках. В исследовании рассматриваются условия, сложившиеся в средневековой Европе и на Среднем Востоке. Его автор рассматривает вопрос, наблюдался ли в Золотой Орде рост средневекового населения до прибытия Черной Смерти в середине XIV века. В исследовании рассматривается степень уменьшения населения, и его влияние на политическую дестабилизацию. Автор отмечает, как бубонная чума была использована в качестве оружия монгольскими армиями. Исследование рассматривает такие экономические последствия, как упадок определенных профессий и ремесел, угроза продовольственному снабжению и подорожание трудовых ресурсов, приведшие к инфляции. Оно также рассматривает социальный кризис, вызванный внезапной смертью существенной части населения.

Результаты исследования: за ростом урбанизации с XIII до середины XIV века последовало резкое уменьшение населения и упадок городских центров начиная со второй половины XIV века. Черная Смерть также привела к перенаселенности, поскольку большинство центров оседлого населения пришли в упадок, в то время как некоторые оседлые регионы избежали чумы, как это случилось и со многими кочевническими группами населения, менее уязвимыми по отношению к эпидемии. Автор также анализирует упадок литературного языка и рост религиозности. Наконец, данное исследование рассматривает восстановление уровня населения, начиная с середины XV века.
\end{abstract}

Ключевые слова: Черная Смерть, уменьшение населения, политическая дестабилизация, экономический кризис, социальный кризис, деурбанизация, литературные языки, религиозность

Для цитирования: Schamiloglu U. The Impact of the Black Death on the Golden Horde: Politics, Economy, Society, Civilization // Золотоордынское обозрение. 2017. T. 5, № 2. C. 325-343. DOI: 10.22378/2313-6197.2017-5-2.325-343

Сведения об авторе: Юлай Шамильоглу - Ph.D. (история), профессор, департамент немецкого, скандинавских и славянских языков, Висконсинский университет в Мадисоне, ORCID: http://orcid.org/0000-0003-0658-1267 (1220 Linden Drive, Madison, WI 53706, USA). E-mail: uschamil@wisc.edu 